\title{
From Mary's Motherhood to the Immaculate Conception: An Iconographic Analysis of Marian Art in Spain during the Tenth to Nineteenth Centuries
}

\author{
Antonio Moreno-Almárcegui ${ }^{1}$ and Germán Scalzo ${ }^{2, *(D)}$ \\ 1 Facultad de Ciencias Económicas y Empresariales, Universidad de Navarra, Campus Universitario, \\ 31009 Pamplona, Spain; anmoreno@unav.es \\ 2 Facultad de Ciencias Económicas y Empresariales, Universidad Panamericana, Augusto Rodin 498, \\ 03920 Ciudad de México, Mexico \\ * Correspondence: gscalzo@up.edu.mx
}

Citation: Moreno-Almárcegui, Antonio, and Germán Scalzo. 2021 From Mary's Motherhood to the Immaculate Conception: An Iconographic Analysis of Marian Art in Spain during the Tenth to Nineteenth Centuries. Religions 12: 1061. https://doi.org/10.3390/ rel12121061

Academic Editors: Manuel Lázaro Pulido, Ricardo Piñero Moral and Marina Montesano

Received: 1 November 2021 Accepted: 26 November 2021 Published: 30 November 2021

Publisher's Note: MDPI stays neutral with regard to jurisdictional claims in published maps and institutional affiliations.

Copyright: (c) 2021 by the authors. Licensee MDPI, Basel, Switzerland. This article is an open access article distributed under the terms and conditions of the Creative Commons Attribution (CC BY) license (https:/ / creativecommons.org/licenses/by/ $4.0 /)$.

\begin{abstract}
This article analyzes Marian art in Spain from the tenth to nineteenth centuries in order to show how popular piety represented Mary's motherhood. Through art, including architecture, painting, sculpture, and oral preaching, a popular image of Mary emerged and, in turn, became key for understanding the history of the family in western Catholic countries. Studying the evolution of Marian iconography during this thousand-year period reveals a kind of grandeur, and then a certain crisis, surrounding Mary's motherhood. This crisis specifically involves the meaning of the body as an effective sign of the personal gift-of-self. We argue that this process ran parallel to growing problems in theological culture related to reconciling the natural and supernatural realms, and we further sustain that it contains a true cultural revolution, a shift that is at the origin of many later transformations. This interpretation helps better understand the dilemmas surrounding the history of the family in the West, and specifically of motherhood, from the point of view of the Christian tradition.
\end{abstract}

Keywords: the Virgin Mary; motherhood; family; Marian iconography; natural; supernatural; logic of the gift

\section{Introduction}

Between the eleventh and thirteenth centuries, when the first universities were founded, an effort to rationalize faith emerged, prompting a more systematic development of sacramental doctrine. This intellectual change gave rise to a clearer separation between the supernatural order (founded on faith) and the natural order (founded on reason), between the spheres of redemption and creation. It also gave rise to a new problem, namely the relationship between the natural and supernatural realms in light of their new-found separation. This new problem profoundly impacted how Christians came to understand the family as a reality that, following the systematization of sacramental doctrine, made marriage one of the seven sacraments of the New Law, and became both natural and supernatural. New doctrinal tensions awakened interest in and a new understanding of the Holy Family's role in the work of redemption. Therein, the human and the divine, the flesh and the spirit converge in singular perfection. Thus, the Holy Family came to be founded both on relationships of consanguinity and grace.

Yet, as becomes immediately obvious, when it comes to consanguinity and grace, Mary and Joseph's positions diverge. Mary is the true mother of Jesus, God, and man, while Joseph is only Jesus' putative father (Moreno-Almárcegui 2016). Mary's motherhood contains a unique union between the natural and supernatural realms, between the flesh and the spirit, between the bond derived from consanguinity and the one founded on grace. 
This article aims to examine how Mary's unique motherhood was represented and how that representation changed throughout eight centuries. It will do so by analyzing works of Marian art in Spain. Indeed, starting in the eleventh century, adoration of the Virgin Mary began to spread throughout European countries (Sabbé 1951; Christian 1976), which led to the development of a certain mass culture that crystallized in the creation of thousands upon thousands of Marian representations. The first pieces consistently depict the Virgin holding the Christ Child, that is to say, believers consistently saw Mary's motherhood depicted. Thus, adoration of the Virgin Mary contains an exaltation of her motherhood, both human and divine. In this way, at the core of Mary's person, i.e., her motherhood, the orders of creation and redemption merge in a particularly strong and exemplary way. In other words, in her relationship with her son, which constitutes the foundation of her identity and her most important mission, consanguinity and grace go hand in hand.

We will see how, over time, representations of Mary's motherhood changed and, from the beginning of the Modern Age, lost consistency. At first, Mary's motherhood was envisaged as the archetype of perfect femininity; in the Modern Age, at least in Spain, this femininity-motherhood archetype began to compete with the archetype associated with the immaculate conception. Therein, she is seen as a young woman of extraordinary beauty and charm; alone and without her son, that is, without strong ties that define her identity, she instead stands in glory with an expression of freedom and power that reflects triumphant grace.

To demonstrate this change, we will analyze the more than 400 works of art presented by Trens (1946), who brought together Marian art in Spain across heterogeneous media, including frescoes, miniatures, panels, sculptures, paintings, altarpieces, engravings, and religious cards. This diversity guarantees the sample's representativeness, and we will focus on overviewing a period (century) rather than on isolated works, breaking down pictures, paintings or miniatures into their most significant elements, representation, and evolution over time. With this, we intend to show how Mary's motherhood and its evolution was understood and represented. Images of Mary were contemplated en masse and thus were a powerful source of inculturation. Seen as the perfect model of motherhood, imitating her became a profound aspiration for many.

\section{From Mary's Maternal Body to the Immaculate Conception}

According to the sample that Trens (1946) collected, as seen in Figure 1, devotion to the Virgin Mary through art hit its highest point around the fifteenth century, remained relatively high during the sixteenth and seventeenth centuries, and then began to decline in the eighteenth century. In that sense, this graph suggests that the crisis surrounding devotion to the Virgin Mary began in the sixteenth century. However, we submit that the construction and restoration of shrines and places of worship better reflects the historical evolution of this devotion.

On the other hand, Figure 2 reveals how the format used evolved, reflecting technological change, passing from majority frescos and miniatures to the use of panel sculptures, reliefs, and altarpieces during the fifteenth and sixteenth centuries, which then were gradually replaced by representations on canvas, engravings and religious cards. The latter points to the emergence of a much more powerful mass culture at the end of the Modern Age thanks to the printing press. In this sense, the sample adequately reflects the evolution of how Marian iconography was represented in each era, which suggests that the sample presented adequately represents the whole. 


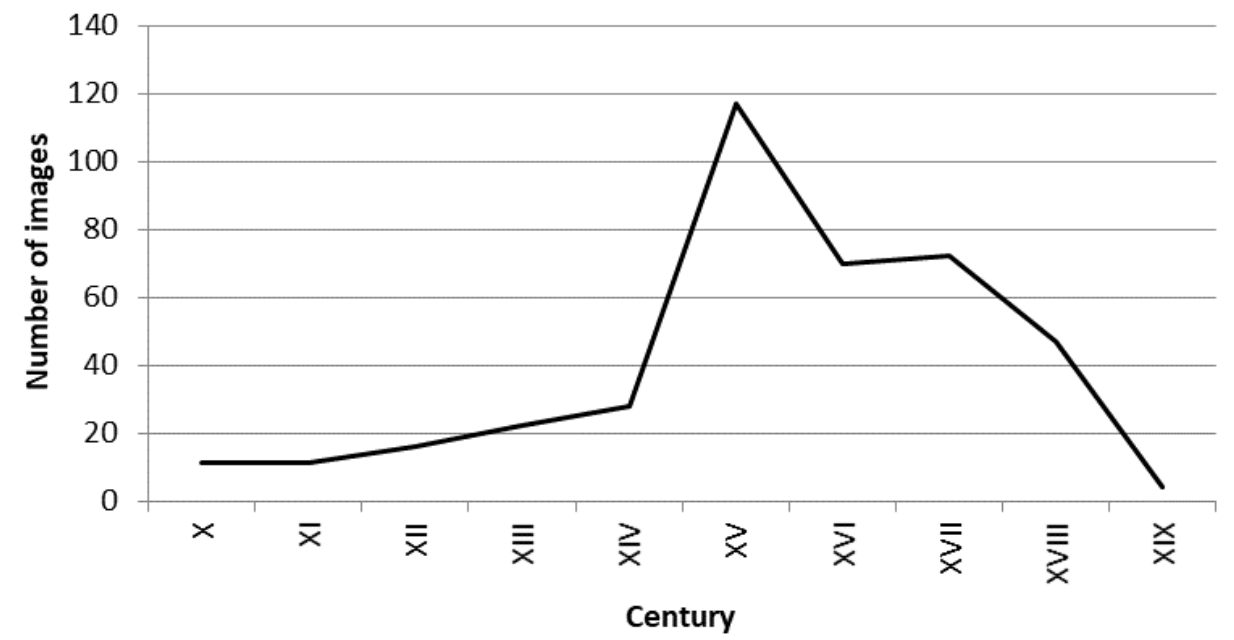

Figure 1. Number of images of Mary in the work of Trens by century (1946) Source: Authors' elaboration based on Trens (1946).

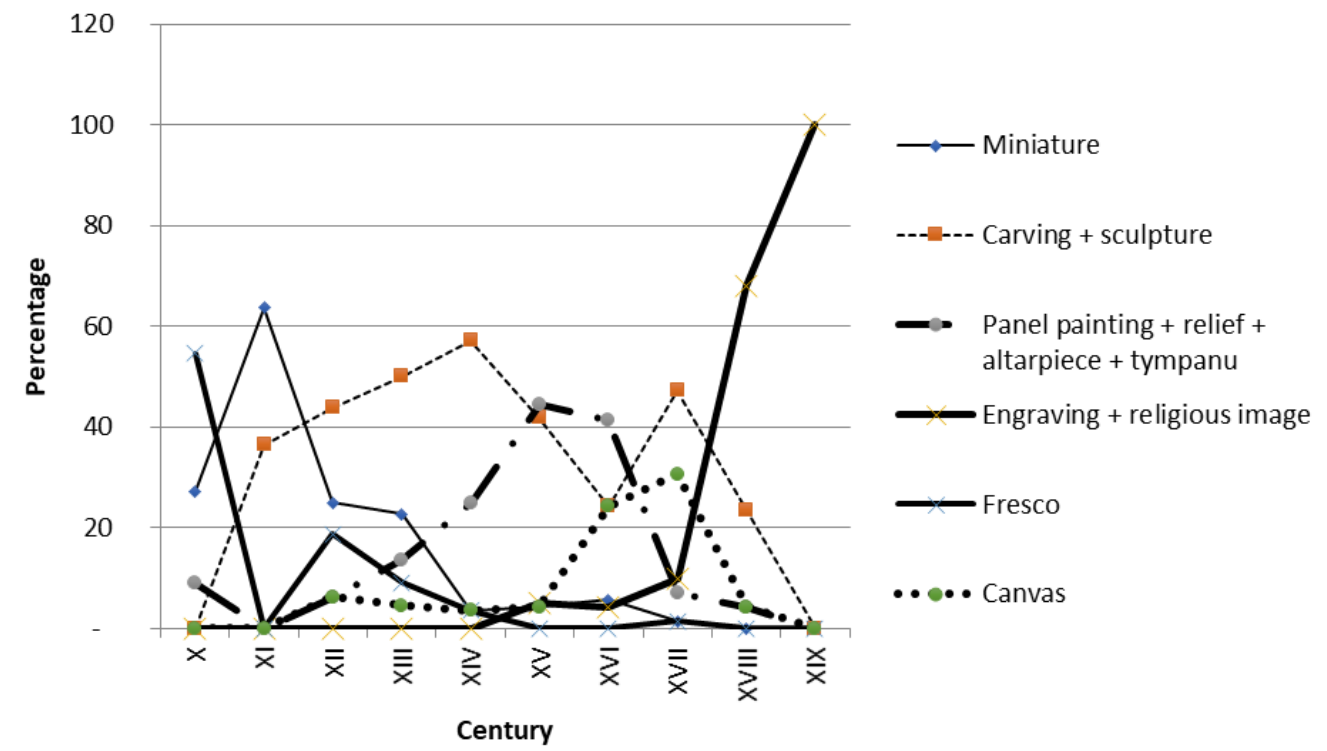

Figure 2. Different types of mediums used in representations of Mary by century. Source: Authors' elaboration based on Trens (1946).

The centrality of her son is evident in Mary's motherhood; she is the Lord's "servant," an instrument in the service of redemption. For this reason, when studying the representation of her motherhood, we take a relational approach and aim to provide a detailed examination of the way in which the mother-child relationship is represented. We examine the relationship starting from the logic of the gift, which corresponds to the appropriate framework for studying a mother-child relationship. In the context of relationships based on the logic of gift, it is often said that the subjects put themselves into what they give with the intention of founding or sustaining the relationship (Caillé 2000; Godbout and Caillé 2010). In a sense, the person puts her very self into what she gives; what is given and who gives it come together, which is why giving becomes giving of oneself (Moreno-Almárcegui and Scalzo 2019; Polo 2015; Haya 1997).

This study highlights relationships' dual dimensions, namely their bodily and spiritual implications. In this specific case, using iconographic representations of the consanguineous and supernatural dimensions of the relationship in question, we examine how both vary over time and are related to each other. 
First, to analyze the human dimension of the mother-child relationship, we will examine maternal representations of Mary's body. ${ }^{1}$ The maternal body is a visible and concrete sign of the mother's gift-of-self to the child. This notion presupposes the idea that, by surrendering the body, mothers uniquely surrender themselves in pregnancy and lactation. Thus, the maternal body appears as a gift to her child.

It is true that, in many gift-based relationships, putting oneself into that which is given is mostly a symbolic act. However, in the case of motherhood, it is undoubtedly tangible; by giving of their bodies to their children, they give over themselves. For mothers, the body itself, which in the context of a relationship is an expression of the person, is the gift-of-self. For this reason, the resulting relationship becomes a source of primary recognition in the lives of the protagonists, involving them in a radical way (Scalzo et al. 2018). Children come from their mothers (and their fathers), which, together with a shared life, gives rise to intense physical, mental, and spiritual intimacy. We are, therefore, interested in analyzing how this intimacy is represented in the case of Mary and the Christ Child, and if it appears to evolve over time.

Second, to analyze the more spiritual dimension of this relationship, we will examine the signs that speak to its psychological-spiritual aspects. This includes artistic manifestations that try to highlight what we could call the most spiritual aspects of Mary's relationship with her son, and therefore Mary's divine maternity, i.e., since the Christ Child is also the son of God, Mary is seen as the mother of the universal Church. We argue that, throughout the nine centuries under study, bodily maternal giving represented in Marian iconography tends to lose importance in favor of psychological-spiritual giving, resulting in increased spiritualization and universalization of this mother-child relationship. This trend intends to highlight the splendor of grace in human relationships. Here we suggest that the way in which this exaltation was carried out obscures the meaning of human, corporal maternal dedication. This development may be related to a certain naturalization of the body associated with the fact that the body lost its meaning as a gift-of-self.

In the case of motherhood, pregnancy and lactation explicitly represent the body as a gift-of-self. ${ }^{2}$ Figure 3 shows how representations of Mary nursing or pregnant evolved over the centuries (see Appendix A, Figure A4a,b). Although some fluctuation is present, possibly due to the small sample size, the underlying trend leaves no room for doubt: in the first two centuries under study, Mary appears pregnant, or breastfeeding in $22 \%$ and $33 \%$ of the images in which she is with her son. These percentages fall in the following two centuries, the twelfth and thirteenth, to rise again in the fourteenth and fifteenth centuries (during the Gothic period). The percentage in fifteenth century $(20 \%)$ was never again reached after that. Indeed, starting in the sixteenth century, these maternal manifestations began to lose importance to the point of almost disappearing from Marian iconography.

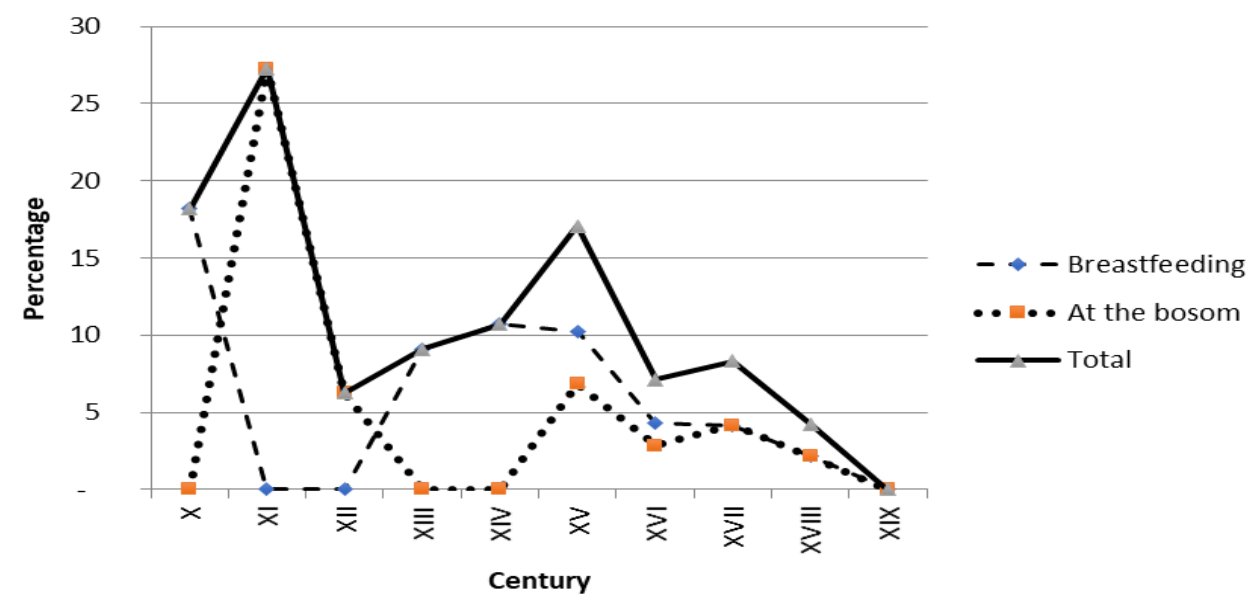

Figure 3. Representations of Mary nursing or pregnant (Spain, percentage of total works by century, tenth to nineteenth centuries). Source: Authors' elaboration based on Trens (1946). 
However, this iconographic "accounting" does not fully reflect reality. Indeed, there are two invocations in which Mary is explicitly represented pregnant, including Our Lady of Hope (see Appendix A, Figure A4a) and Our Lady of the O (also called Our Lady of the Expectation). Some testimonies suggest that these types of images were abundant in the past, however, according to Trens, they were destroyed en masse during the eighteenth and nineteenth centuries:

From the apocalyptic Virgin comes another iconographic type, that of Our Lady of Hope, or of the $\mathrm{O}$. This representation, in all its starkness, was typical of a time of great faith and little hesitation that is now quite rare. This is because, in the eighteenth and nineteenth centuries, many dioceses ordered images of this kind to be taken out of circulation; some were even being buried in cemeteries and others stored in attics where they awaited fire or antique dealers (Trens 1946, p. 75). ${ }^{3}$

Trens seems to suggest that, starting from the eighteenth century on, a "new sensibility" emerged that he himself seems to share, i.e., one distressed by this representation of pregnant Mary. At the very least, it seems to him an inappropriate way of expressing Mary's motherhood. If Trens' assessment is true, it is very likely that Figure 3 underestimates the decline of images of Mary pregnant during the Modern Age.

He also suggests that the iconographic type prior to Our Lady of Hope or of the $\mathrm{O}$, the apocalyptic Virgin, ${ }^{4}$ usually represents Mary with a "radiant solar disk on her belly, with human features, and, at its center an embryonic, completely naked figure of the Christ Child" (Trens 1946, pp. 77-78). Thus, representations of the apocalyptic Virgin and Our Lady of Hope both depict Mary with the Christ Child in her womb. The most marked difference between them is the much more realistic and natural representation of Mary's pregnancy in Our Lady of Hope or Our Lady of the O.

The other iconographic change related to the apocalyptic Virgin corresponds to the immaculate conception. Although present throughout the West, it reached particular grandeur in Spain and its territories. In representations of the immaculate conception, Mary appears as a young woman of singular beauty and vitality and is without child (see Appendix A, Figure A1b). Everything in the image tends to exalt the splendor, beauty, and loveliness of Mary's virginal purity. These images clearly aim to present Mary in her virginity as a singular example of feminine perfection expressed with her youth, beauty, and joy, making her a desirable model of femininity for young women. Thus, her immaculate conception and her virginity are visually associated. Angels surround the Virgin and, crowned with twelve stars, she appears high on a cloud. The entire scene features a glorified Mary, situated beyond history in heaven. In some cases, she is under the watchful eye of the Trinity who looks at her with veneration, presenting her as a desirable model for God himself. In this way, Mary hints at the reward that awaits those who imitate her.

The triumph associated with the iconographic model of the immaculate conception undoubtedly explains the evolution reflected in Figures 4 and 5. In Figure 4, the importance of this stage in Mary's life is clear, and the evolution thereof leaves no room for doubt. In the first centuries of the period studied, representations of Mary-mother clearly dominate (over $86 \%$ during the twelfth to fourteenth centuries). ${ }^{5}$ Starting in the fifteenth century, this importance declined consistently until reaching $60 \%$ in the seventeenth century, in favor first of Mary-young woman, to finish, starting in the sixteenth century, with representations of Mary-young woman, unmarried, and without Child. Representations thereof grew to $25 \%$ in the seventeenth century. Her motherhood and her marriage disappear from these representations. 


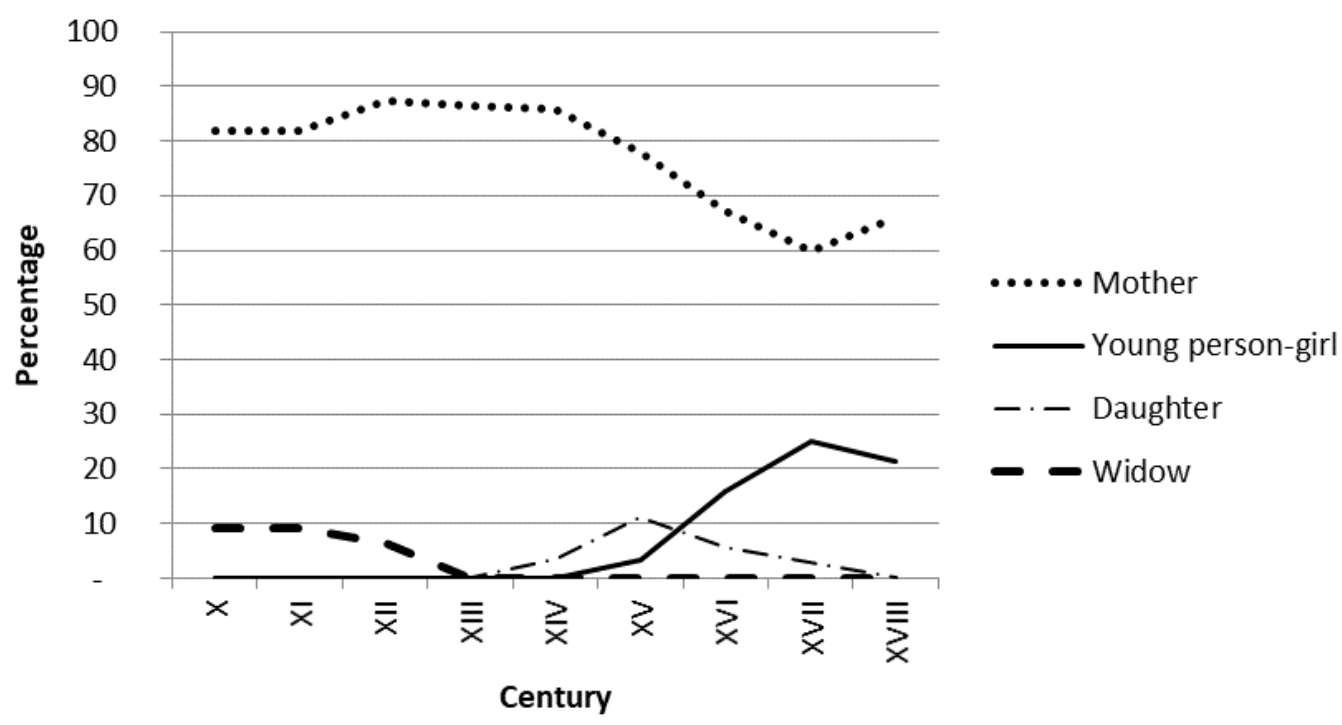

Figure 4. Representations of Mary as a young person or girl (Spain, tenth to eighteenth centuries). Source: Authors' elaboration based on Trens (1946).

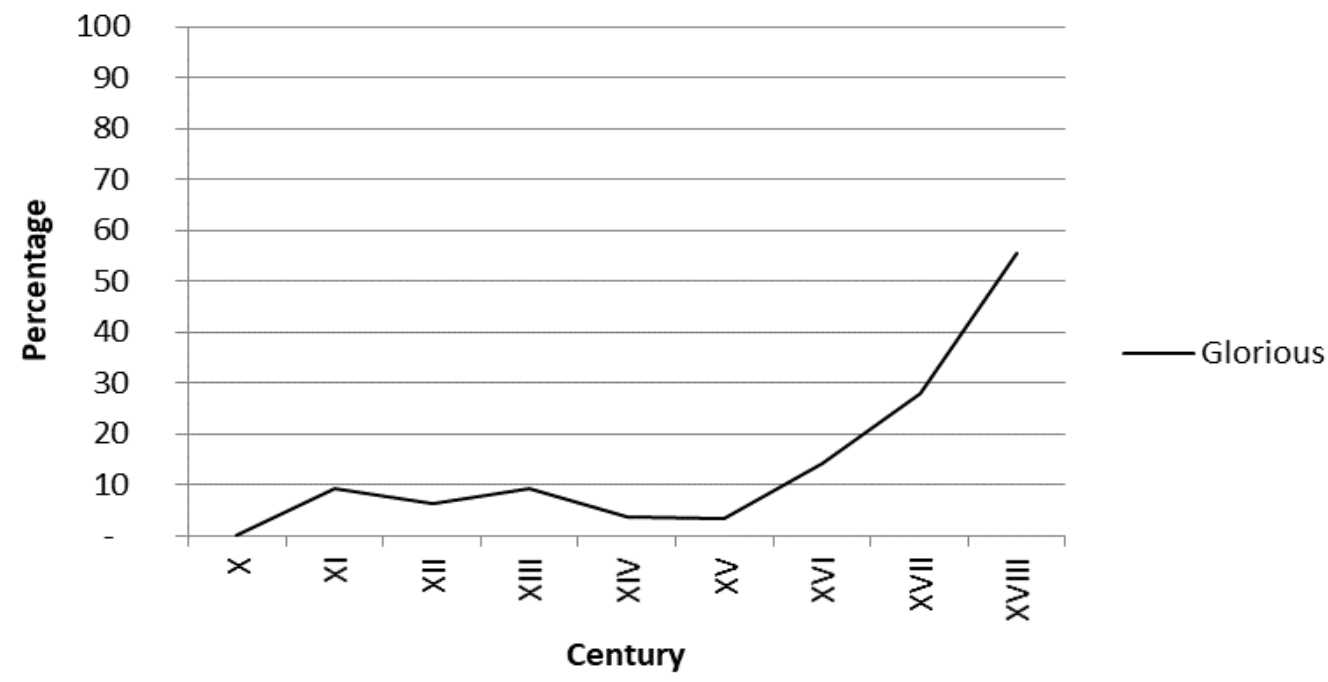

Figure 5. Presentations of Mary as glorious in heaven (Spain, tenth to eighteenth centuries). Source: Authors' elaboration based on Trens (1946).

Similarly, Figure 5 represents the percentage of images in which Our Lady appears glorified, visually situated in the sky (on a cloud, surrounded by angels). Although this type of scene is present throughout the centuries, it was not until the sixteenth century that it began to acquire importance, growing throughout the Modern Age until reaching 55\% of all representations in the eighteenth century. The graph below depicts this remarkable change.

\section{The Mother-Child Relationship: An Analysis of Mary and the Christ Child's Positions and Gazes}

This evolution has a lot to do with the position in which Mary appears (Figure 6), which, in turn, influences how Mary holds or relates to the child (Figure 7). 


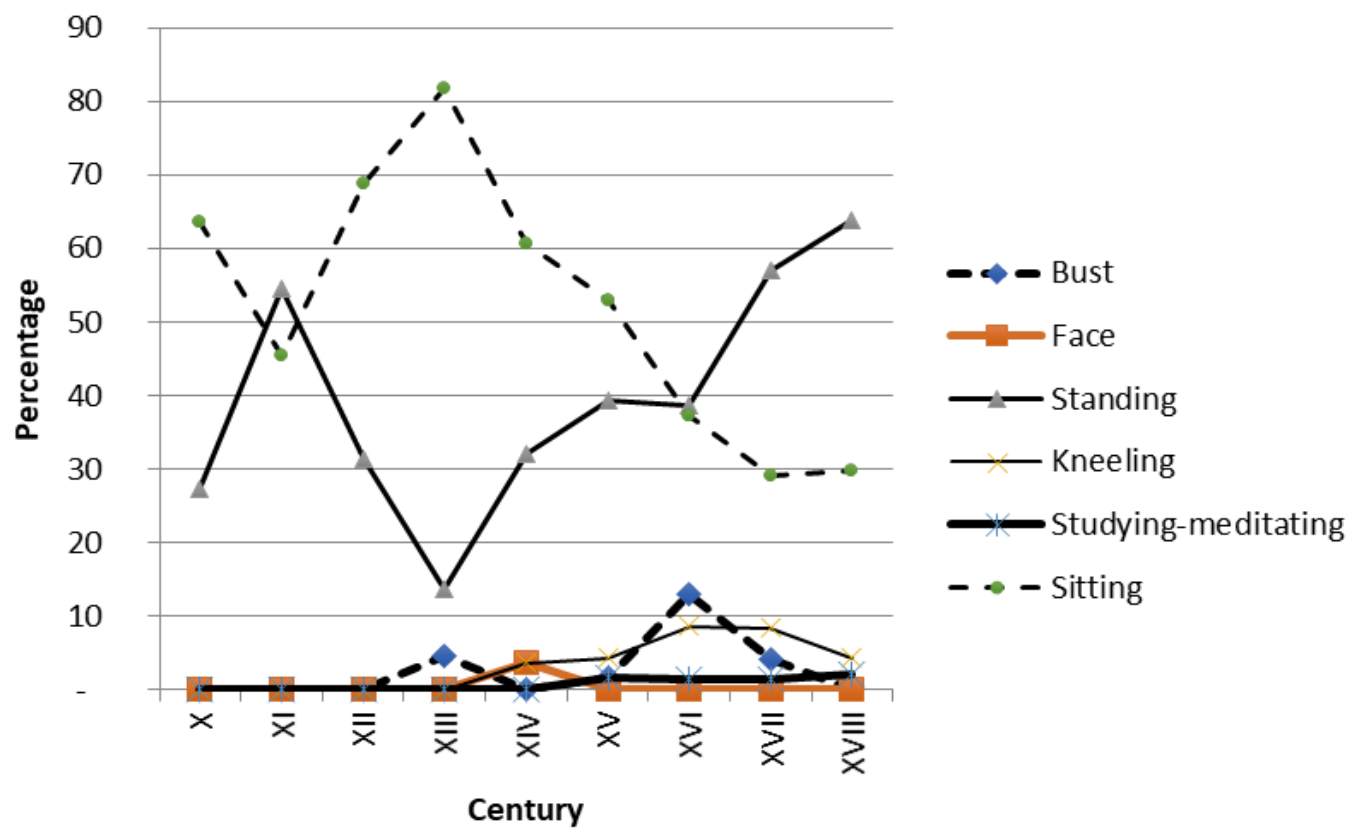

Figure 6. Presentations of Mary's posture (Spain, tenth to eighteenth centuries). Source: Authors' elaboration based on Trens (1946).

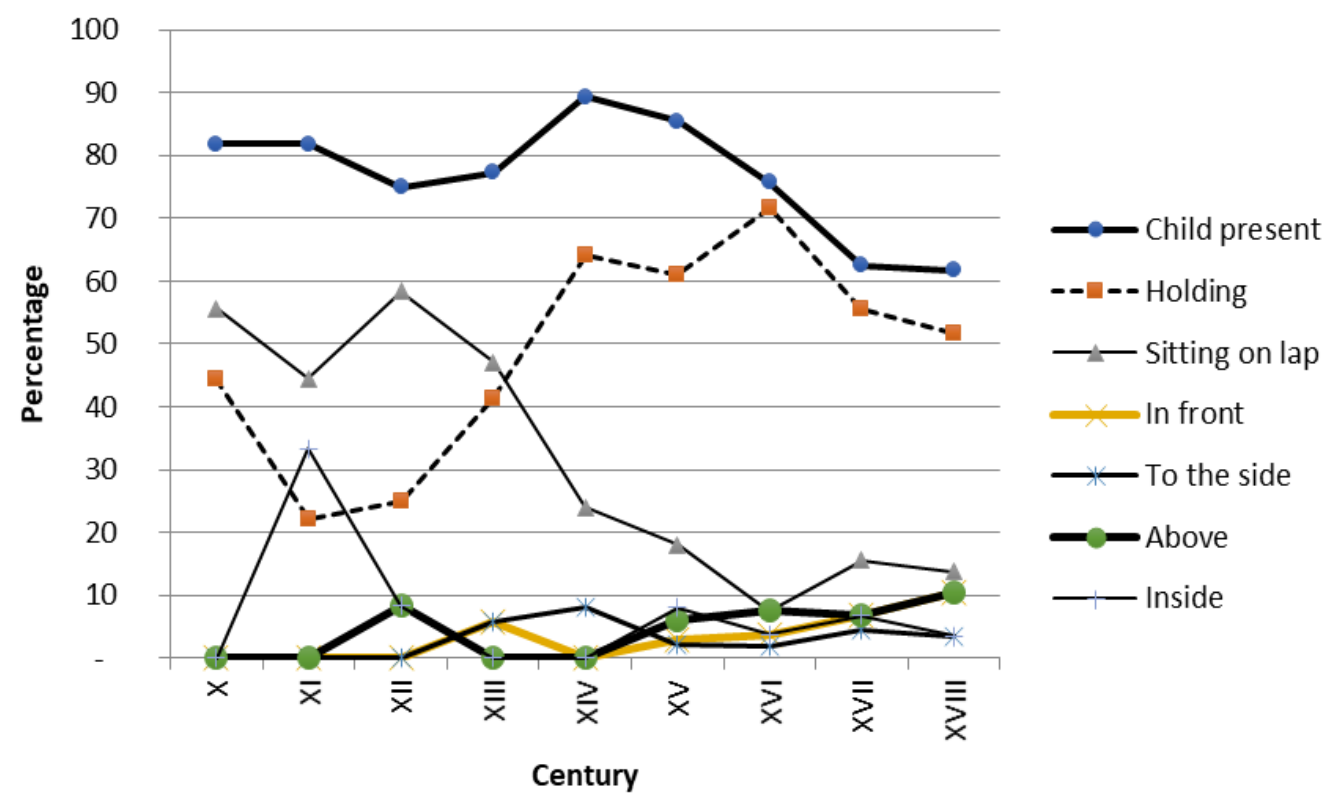

Figure 7. The Christ Child's position with respect to Mary (Spain, tenth to eighteenth centuries). Source: Authors' elaboration based on Trens (1946).

Mary mostly appears in two positions, namely sitting (46\%) and standing (43\%). ${ }^{6}$ However, her position varies greatly over time. Starting in the first centuries until the fifteenth century, Mary appears mostly seated. However, after a peak in the thirteenth century, representations of Mary seated tend to decline in favor of standing. In the sixteenth century, both representations were balanced, while standing began to dominate starting from the seventeenth century onward. This could be simplified by saying that Mary goes from sitting to standing.

Both positions have liturgical significance (Ratzinger 2001). In the liturgy, sitting is an appropriate posture for meditating and listening; it expresses a willingness to listen attentively and with interest. People stand for those who deserve respect and, before 
the majesty of God, they kneel. They sit down when they want to give someone their full attention, receive, welcome, or listen. Moreover, it is a sign of rest, familiarity, and trust. Undoubtedly, all these senses are deeply maternal since mothers listen carefully and welcome others in a climate of trust and familiarity. But celebrants and leaders also assume this position, as do teachers and bosses when presiding with authority. These two senses seem to be opposed; however, the sense in which Mary is depicted leaves no room for doubt: she is crowned and seated on a throne, an unequivocal sign of authority or royalty. ${ }^{7}$ That is why this genre is usually called "Virgin in Majesty." Majesty is proper to God or kings, and both have the supreme power to judge.

At that time, Mary usually appeared with the Christ Child sitting on her lap (Figure 7, See Appendix A, Figure A1a). Thus, Mary is seated on a throne and the Child is seated on his mother. In other words, the child's throne is his mother. Jesus' royalty (and therefore his justice, since he also appears seated) is based on his mother, who is his son's "Throne of Wisdom". This is a radical reversal. God the judge is an infant supported by Mary; Almighty God is presented as a gentle infant held by Mary in her lap, a maternal sign par excellence. Mary's power as the Throne of Wisdom derives from her motherhood, which most of her devotees interpret as a source of mercy and hope.

Undoubtedly, this representation is an exaltation of Mary's motherhood. Moreover, this motherhood reconciles the dual senses of welcoming, trusting, and listening in a familiar atmosphere and the majestic, judicial one. Mary, behind Jesus, is the perfect mediator who knows how to transform that justice into mercy thanks to her motherly wisdom, thus winning her son for us. This represents a simple and moving visual solution to the dilemma between justice and mercy in that the justice of God-a child-is sustained by Mary's maternal mercy.

Representations of Mary change radically when she stands up. Standing is a gesture of victory. At the end of a battle, the winner remains upright and standing and, with it, the faithful are united to Christ's victory. Those willing to embark on a journey also assume this position; it corresponds to free men who are no longer slaves, but rather friends of God able to look him in the face and address him. A child of God free from sin assumes this posture, having received the reward of glory. Images associated with the immaculate conception take this posture (see Appendix A, Figure A1b).

This change in Mary's position explains why the Christ Child began to be depicted as being held in his mother's arms more, instead of sitting on her lap (Figure 7). As a consequence, the child goes from a majestic, seated posture to being in his mother's arms (see Appendix A, Figure A3a,b). The image loses its majestic feeling and reinforces Jesus' filial side.

Indeed, the Romanesque child-judge is a somewhat strange, unnatural representation of childhood. In fact, his infantile aura is obscured by his real condition, as if this period were incapable of representing childhood as a specific stage in human life. ${ }^{8}$ In the following centuries, at the same time that the child passes into his mother's arms and the relationship takes on a much more natural representation, he also is depicted with a more clearly childlike quality.

Just as physical contact can be the visual materialization of a certain maternal-bodily intimacy, the gaze can be considered the visual materialization of a certain maternal-spiritual intimacy. Studying the gazes between Mary and her child offers a more complete view of the nature of the mother-child relationship and, therefore, of how Mary's motherhood was represented in terms of its psycho-spiritual quality. The gazes observed in Trens' compilation are explored below.

The first corresponds to Mary and child looking straight ahead (a), a representation that dominates at the beginning of the period studied and reached its peak in the Romanesque era (Figure 8, Appendix A, Figure A2a). The most reasonable interpretation of this gaze is that both are looking at the devotee who comes to them. This seems to be the most consistent interpretation with the representation as a whole: Mary and child are seated in a trusting posture and appear willing to listen. Logically, the fact that they are 
looking out suggests that they are looking at the person contemplating the image. Mary and Jesus' gaze "unite" in the believer.

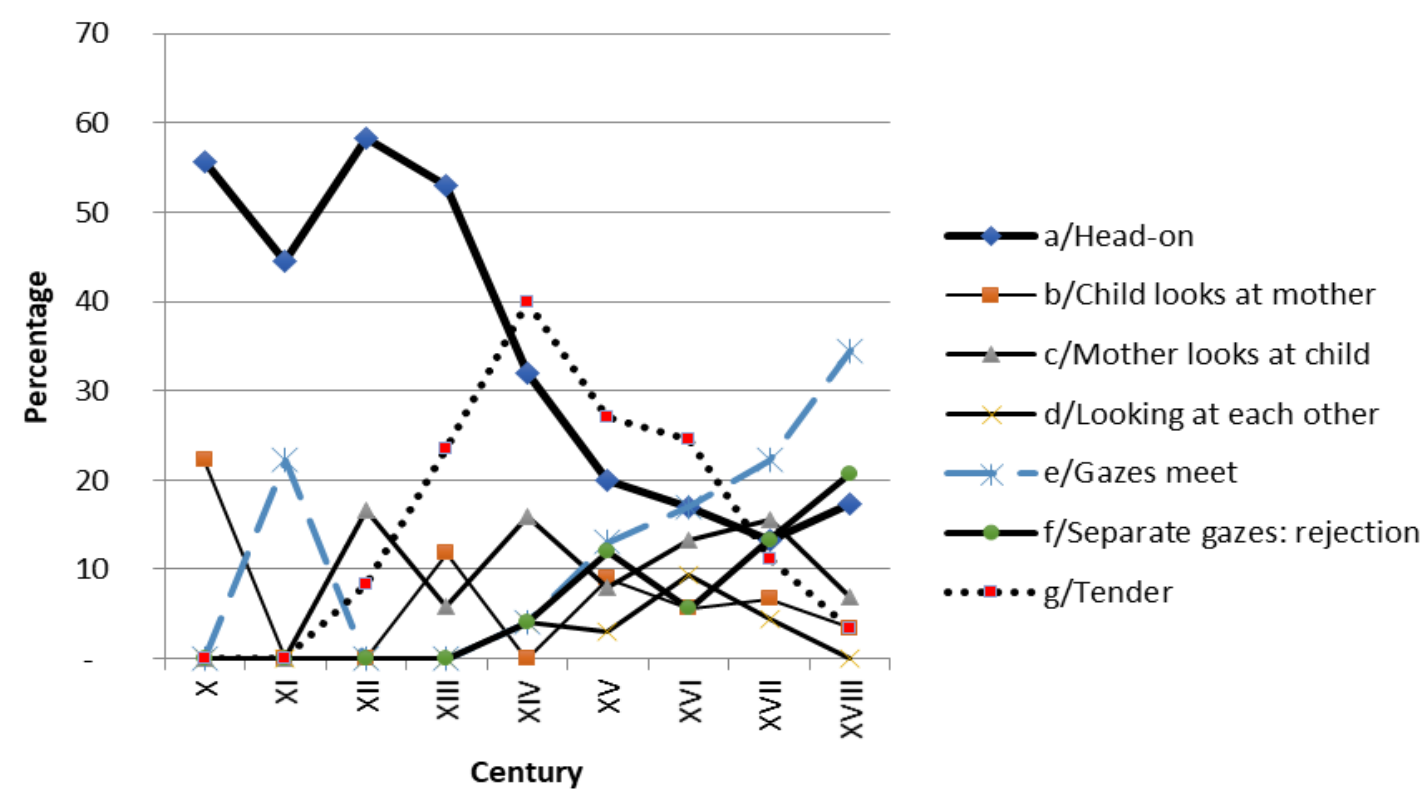

Figure 8. Mother-child gaze in representations of Mary (Spain, tenth to eighteenth centuries). Source: Authors' elaboration based on Trens (1946).

The representation most similar to the outward gaze is type e (both Mary and child's gazes converge on a third party or parties represented in the image). If we look at the evolution of types a and e, (Figure 8), we see that, in a certain sense, they move in opposite directions. We might reasonably venture that both types intend to express the same thing, with the difference that the technique of perspective had not yet been mastered in the first centuries (and therefore converging gazes were not possible). If this interpretation is true, type e also expresses that both Mary and child look at the devotee in unison. Thus, if we add types a and e together-Mary and child looking at the devotee- they constitute the largest classification with $40 \%{ }^{9}$

Another category refers to Mary and child looking at each other (see Appendix A, Figure A2b). We have distinguished two types herein, namely the gaze expresses tenderness (g, $20 \%$ of the cases) or they simply look at each other, but with a certain seriousness, in what we could qualify as a more concentrated gaze ( $d, 4 \%$ of the cases). Thus, when mother and child look at each other, a tender and trusting look is more common.

The other category of gazes corresponds to those that do not meet, either because the Christ Child looks at his mother, but not vice versa ( $b, 7 \%)$, or because the mother looks at the child, but he does not look back at her (c, 10\%), or because neither looks at the other, an expression of anger between them (f, $9 \%$ ). The latter type comes about very late (it does not appear until the fourteenth century) and tends to increase in every century, reaching $21 \%$ of cases in the eighteenth century. Often, anger is motivated by Mary's rejection of the cross that her son takes up.

If we simplify Figure 8 by reducing the gazes to three categories-mother and son look at the devotee $\left(x^{10} 40 \%\right)$, they look at each other $(y, 1124 \%)$ and they do not look at each other $\left(z_{1}^{12} 26 \%\right)$-we obtain Figure 9 . This graph more systematically presents the evolution of the gazes between Mary and the Christ Child. 


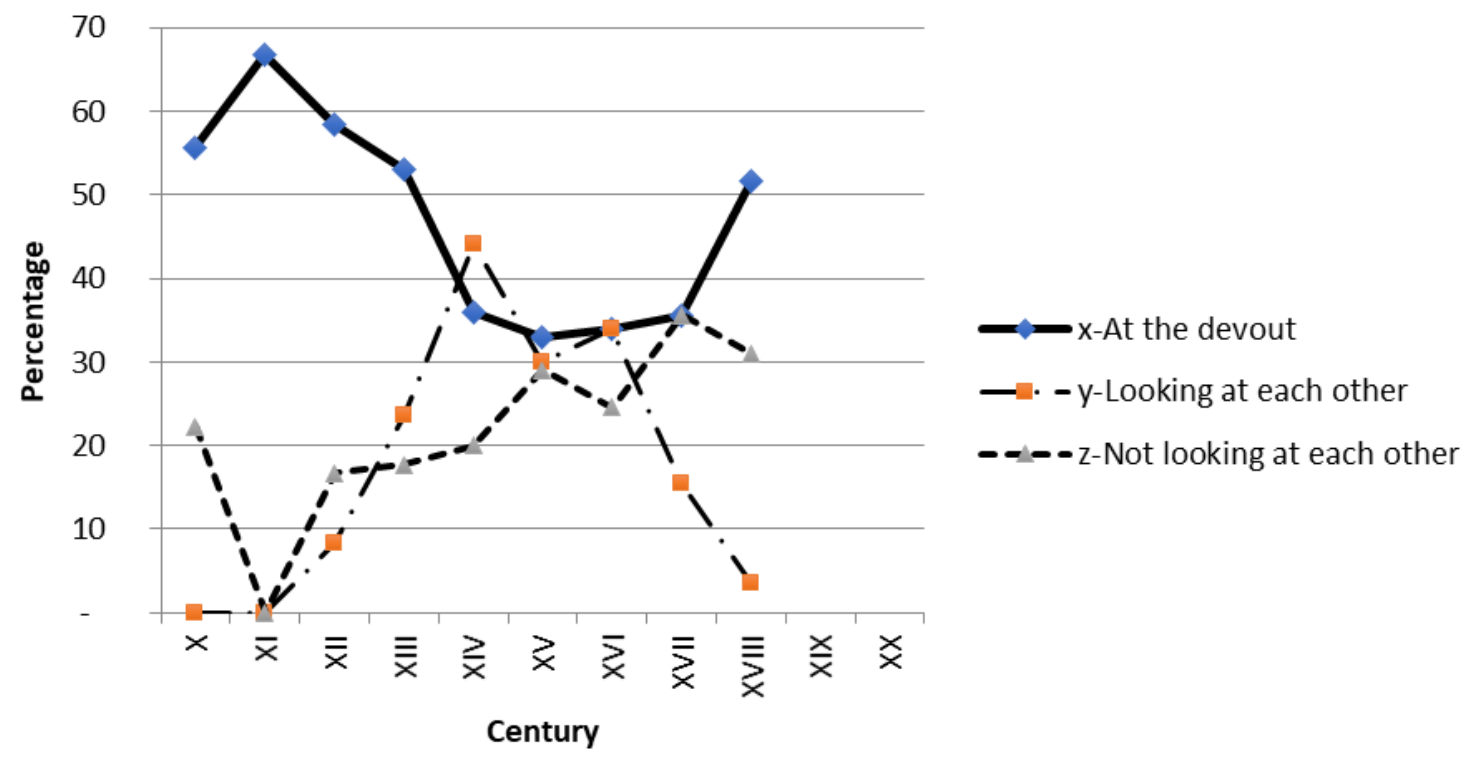

Figure 9. Mother-child gaze in representations of Mary (Spain, tenth to eighteenth centuries. Simplified). Source: Authors' elaboration based on Trens (1946).

During the tenth to thirteenth centuries, there is an overwhelming majority of type $x$ (over 50\%), with Mary and Jesus looking at the devotee. This also coincides with the predominance of images of Mary enthroned in a majestic position with her son seated on her lap.

This changes profoundly in the following centuries. From the fourteenth to the seventeenth centuries, type $x$ is reduced to a third of the gazes, due to the increase of the other two types, especially type $y$, which became very important during the fourteenth to sixteenth centuries, mainly due to the increase in the crossing of tender and trusting mother-son gazes during those centuries. If tenderness is the expression of the balance between body and soul, head and heart, reason, and affectivity, the natural-supernatural, the series shows that the climax of the mother-son relationship peaked in the fourteenth century. If in the previous stage Mary and child look attentively at the devotee in a listening posture, now it is the devotee who looks jubilant at the unity found in this mother-son relationship.

After that, depiction of a tender relationship began to decline, and did so definitively starting in the seventeenth century in favor of type $z$ gazes, i.e., those that do not meet, which then reached its peak in the seventeenth century, at the same time that type y gazes (where mother and son gaze at each other) declined until almost disappearing. Of note, within group $z$, type $f$, in which mother and son reject the other's gaze, tends to grow the most.

This gives the impression that, after peaking in the fourteenth century, the mother-son relationship tended to lose its previous harmony, entering a time of increasing difficulty that became more acute after the Baroque period. The next section will examine this claim.

\section{The Psychological-Spiritual Nature of the Relationship between Mary and the Christ Child}

We have seen how, when Mary stands up in visual representations, the Child goes from her lap to her arms in what constitutes a more clearly filial position. Therein, the Child tends to remain wrapped in Mary's arms, highlighting his natural condition as a baby, as her son. This change allows us to enter into the psychological-spiritual nature of the relationship between Mary and child from another point of view. 
Indeed, much of the related literature has shown that mothers tend to hold their children on the left side. Although there is no agreement about the ultimate meaning of this behavior, it constitutes a significant aspect of motherhood. Some emphasize that this position places the child over the mother's heart, which is a source of security and peace, taking him back to his origin when his home was his mother's body, and benefiting his development. Others suggest that the left side brings the most affectionate side of the face into view, a reflection of a deep psycho-corporal bond between mother and child (Donnot and Vauclair 2005). Both interpretations agree that the maternal body is a natural home for her child even after birth and that mother and child, through their bodies, establish a deep and unique connection. One is a gift to the other, which expresses the condition of the body as an effective sign of the gift-of-self.

On which side does Mary hold her child in Spanish Marian iconography? The answer is expressed in Figure 10. We have classified the child's position with respect to his mother as follows: left, right, central, at the breast, and separated (Jesus is present, but there is no physical contact).

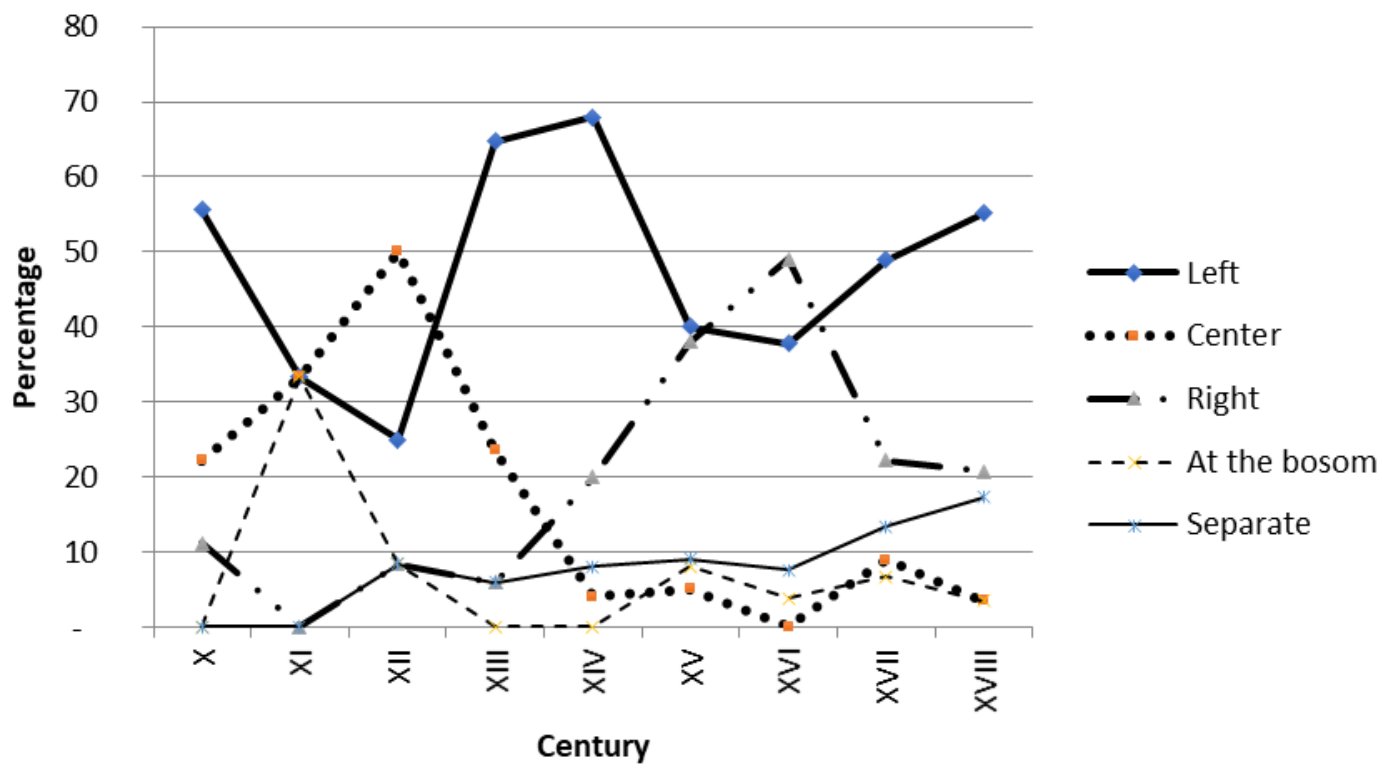

Figure 10. The Christ Child's position in relation to Mary (Spain, tenth to eighteenth centuries). Source: Authors' elaboration based on Trens (1946).

Notably, Jesus appears physically separate from his mother in only $9 \%$ of cases. Their overwhelming physical contact speaks to mothers' physical intimacy with their children, highlighting how relevant the body is to Mary and her son's relationship. Since Mary is also the mother of God, this representation reflects that, transformed by grace, human motherhood can host the most sublime divine realities. Everything in the relationship contributes to divine exaltation. It is also true that physical contact tends to lose importance through time; indeed, representations with no contact reached $17 \%$ of all cases in the eighteenth century.

The majority of representations with contact happen on the left side (46\%) compared to the right side (29\%). They are followed by the center $(9 \%)$ and in the womb $(6 \%)$, in addition to $9 \%$ in which they are separate. Combining the most clearly maternal traits (left side and mother's womb) comes to $52 \%$ (57\% if we only consider images in which there is physical contact between mother and child). Thus, Mary's motherhood is represented as that of a normal mother, where the left side is favored, and mother and son's bodies express a strong psycho-affective bond. 
However, suggestive oscillations emerge if we trace the sample over the centuries; they describe cycles, each one with its own characteristics (Figure 10). In the first cyclefrom the tenth to the twelfth centuries and coinciding with the height of the Romanesque period-maternal postures (at the bosom, left side) vie for primacy with representations that present the child in the center, seated on his mother's lap, the meaning of which was explained above, i.e., Mary seated on a throne, who is herself a throne for her son. The importance of a centered posture reaches its climax in the twelfth century, equaling the other two. At this time, the mother and child mostly gaze outward, attentively listening to the believer, thus inserting the maternal relationship in a majestic, judicial context, and conveying an atmosphere of interest and trust. It is Mary's maternal presence that prevents divine justice from producing fear of God who appears as a child supported by his mother; visually, God is enveloped and sustained by Mary's maternal mercy.

During the following two centuries-thirteenth and fourteenth, which coincides with the Gothic period-representations on the left side dominate (above $60 \%$ ), while the other representations tend to decline in prominence. At no other time did the child's position portray such a maternal atmosphere. In these centuries, crossed gazes between mother and her tender and trusting son peak in the fourteenth century. Mary starts to stand up, causing the whole frame to increasingly lose its majestic appeal, replacing it representations in which Mary's motherhood visually predominates. The Mary's victorious standing position, the tender and trusting gaze between them, all suggest the triumphant splendor of Mary's motherhood and a deep union between mother and son. But is this a self-referential view of Mary and Jesus or, rather, is it the believer who gazes spellbound at mother and son?

This situation changed again during the Renaissance in the fifteenth and sixteenth centuries. Therein, representations of Mary with the Christ Child on the right side surprisingly increased, and then became the dominant position in the sixteenth century. This phenomenon seems more general since it also occurred across Europe (Grüsser 1983). What does it signify?

Despite his unfamiliarity with the specialized literature on the subject, Trens accepted the classical interpretation of the left side ${ }^{13}$ and suggested the idea that the Child on the right side could represent a more spiritual relationship between mother and son. For him, representing Mary with her child on the right likely followed mystical symbolism found in Psalm 40 (Trens 1946, p. 612).

As such, from the fifteenth to the sixteenth centuries, faced with a natural representation of motherhood expressed on the left side, does a more spiritual relationship exclusively founded on grace and expressed on right side begin to be affirmed? This could reflect a wider change. ${ }^{14}$ In the previous medieval tradition, grace—supernatural gift-transforms nature by bringing it to its fullness. This is what Marian iconography tries to represent during the thirteenth century, when scholasticism reached its height. Mary, full of grace, brings her motherhood to its fullness, which translates into an intense bodily and psycho-affective relationship with her son (left side dominates) that is full of tenderness (crossing, smiling and confident gazes). Grace brings Mary's humanity to perfection, which is expressed in her perfect motherhood.

However, after the fourteenth century, representations of Mary seem to tend toward diminished harmony. The supernatural character of the mother-child relationship started to stray from expressions that coincide with all mothers, requiring another visual expression: the right side, opposite the natural one. In the same way, the harmony of the mother-child relationship- expressed in tender and trusting gazes that meet- rapidly loses prominence in favor of representations of the relationship in more problematic terms. The most paradigmatic case is Mary's rejection of the cross, which Jesus embraces. This representation suggests a certain difficulty in reconciling a mother's natural love with her son's supernatural mission. It is not so much that the weight of original sin irremediably damaged nature, since Mary is immaculate from the origin; instead, it seems that grace has lost its capacity to transform natural realities, restoring them to their original splendor. More specifically, motherhood seems to have a series of intrinsic limitations, and grace, 
superimposed on that reality, acts in other directions in parallel and separate from her motherhood.

Finally, during the seventeenth and eighteenth centuries, coinciding with the Baroque and Neoclassical periods, maternal representations resurged; although with some caveats, there were more depictions on the left side. The frequency of representations in which Mary and Jesus are separated (Figure 11) increases, as do, above all, representations with rejecting or adrift gazes between Mary and child. And as we have already seen, representations of Mary alone also increase significantly.

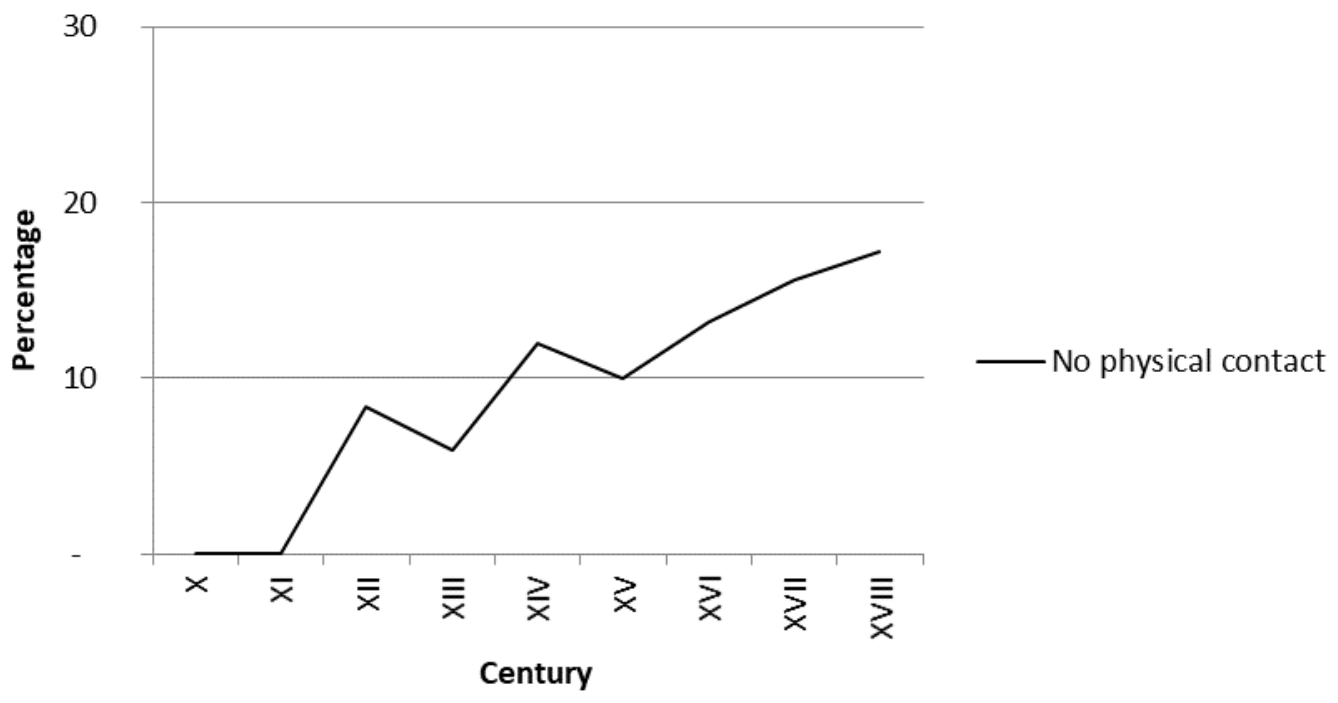

Figure 11. Mother and child separate (Spain, tenth to eighteenth centuries). Source: Authors' elaboration based on Trens (1946).

During this period, representations of immaculate Mary prevail. She is depicted increasingly younger, standing victorious and glorified in Heaven. At the same time, when she appears with her child, they are more often lack maternal, physical contact. The general impression is that Mary's motherhood, while still being very important, is no longer omnipresent; it shares the scene with other representations.

Similarly, during the Baroque and Neoclassical periods, representations of Mary as mother include a dual process. On the one hand, we find a deeply natural, even homelike, representation of the relationship between mother and child. On the other hand, when this relationship is depicted in public or in light of her son's mission, analysis of their physical relationship or gaze reveals a more problematic mother-son relationship.

A more simplified view establishes two general periods: From the tenth to thirteenth centuries, where the options are left-breast versus center, and a second period, from the fourteenth to the eighteenth centuries, where the options are left versus right, and representations of the child in the womb or in the center are marginal.

In the first period, when majestic representations dominate, Mary's role in the work of redemption seems clear, the protagonists look attentively at the devotee, and the harmony and sobriety of the mother-child relationship dominates. This all contributes to visually expressing a balance between the natural and the supernatural, the human and the divine, consanguinity and grace. Mary's role in the work of redemption is expressed in terms of the work of creation, i.e., in the splendor of her motherhood. 
In the fourteenth to fifteenth centuries, Mary's motherhood is expressed in a tender and trusting relationship with her son: affectionate mother-son gazes dominate the representations therein, even above convergent gazes at the viewer. Increasingly depicted as standing and crowned, Mary appears as a triumphant queen with the Christ Child in her arms. In return, these images tend to lose the majestic, judicial character of the previous period. In this representation, a kind of tender joy dominates; the mother-son pair appears self-referential and a clear and explicit relationship with the work of redemption is lacking (except for the crown). A certain naturalism dominates the scene, with a happy relationship between a mother and her child. This period constitutes the golden age of Mary's motherhood.

As of the sixteenth century, the related iconography takes a turn and Mary's motherhood is no longer omnipresent; it appears more frequently as problematic with respect to her son's mission, and when it is represented as totally maternal, it is within a charming home scene far from the public eye.

As a whole, this process suggests a certain privatization of the relationship, with the decline of its redeeming public role. It is no longer so focused on the devotee and becomes more problematic; mother and son look at each other less and less, and even appear angry with each other at times in the context of the cross that Mary, as a mother, resists and her son fully intends to take up. It is as if her "excessively human" motherhood were opposed to her son's salvific work. Her motherhood becomes seen in more subjective psychological-affective terms and is problematically linked to her son's redemptive work. The natural and supernatural are increasingly represented as processes that are difficult to reconcile. Thus, representations of Mary go from her sitting in a motherly, attentive posture with her son sitting on her lap in a majestic posture where she is fully united to her son's redemptive work to Mary as a mother affectionately united to her son, to Mary as a mother whose tender affection for her son makes it difficult for her to accept the consequences of his redemptive work. In this moment, Mary's motherhood tends to lose relevance in favor of Mary as immaculate, where she is increasingly depicted as a glorious, young, single woman without her son.

\section{Spiritualization of Motherhood}

The changes described above take place in a historical context in which Mary's virginity and her immaculate conception are increasingly exalted. In the prior tradition, Mary's virginity ultimately safeguards her divine motherhood, and her maternal relationship with her son constitutes the ultimate foundation of her deepest identity. From the beginning, this relationship is the basis of her contribution to the work of redemption, as well as the task that gives meaning to her life.

Starting in the late Middle Ages, the mendicant orders began to insist on the importance of Mary's virginity and, above all, on her immaculate conception. They aimed to exalt the fullness of the work of grace in Mary. Thus, Mary's perfection is explained as deep harmony between consanguinity and grace, the human and the divine.

This explains their insistence on holiness as the result of a process of spiritual struggle, from which, with the help of the sacraments-especially penance and communion-a Christian will be victorious. That process of struggle results in a new, much more sensitive spiritual awareness. One of the effects of greater spiritual delicacy is a clearer vision of one's own limitations and sharper awareness of the consequences of original sin. Generally speaking, this corresponds to a new historical awareness of the consequences of original sin, seen in a new light and with a greater sense of its gravity. 
In the context of this spirituality, devotion to Mary as mother of God and of all men spread. Before divine justice, she is the mother of mercy. Faced with the disheartening gaze of sin, and in light of a new historical awareness of the consequences of original sin on human nature, an impulse arose to exalt Mary as full of grace. However, in a certain sense, each new Marian dogma has tended toward gradually obscuring the meaning of her humanity by affirming the fullness of grace in her. Did this impact the meaning and role of Mary's motherhood in the work of redemption?

Faced with this, the exaltation of Mary's virginity and immaculate conception reflect the splendor of grace over her human facets in another way. By insisting on her virginity and immaculate conception, related representations show the beauty and joy that grace produces in her. But in this image, Mary's motherhood remains in the background. Moreover, the model of Mary's perfect virginity-increasingly represented as young, alone and single - presents a more individualistic version of femininity that ceases to be universal. It seems to exalt the path to holiness for friars and nuns over the path meant for fathers and mothers.

Another feature of note corresponds to the growing importance that the Frenchstyle cloak acquired in iconography over the centuries. At the beginning of the periodnotwithstanding the greater or lesser technical perfection of the time-Mary is usually dressed in clothes that do not hide her maternal features. Moreover, as artistic technique improved, representations of Mary tended toward more natural depictions of her maternal body. However, this trend ceased around the fifteenth century. From then on, Mary increasingly appeared covered by a cloak often made of rich fabric and embroidered in precious stones, gold, and silver. This cloak has deep theological significance, but, at the same time, holds visual significance as well.

The so-called French cloak, which spread throughout Spain starting in the fifteenth century, is usually a frusto-conical cloak that exposes Mary's often-crowned head and totally hides her body. The visual impact of this cloak is vast: under a stiff cloak, Mary's maternal body disappears from view. This process of "dressing" Mary with a cloak was widely extended to images from previous eras. There is a significant iconographic jump between the Gothic Virgins, with a natural maternal body, and those dressed in a Baroque cloak. This change seems to follow the same line already seen in the images of Our Lady of Hope or of the $\mathrm{O}$. It is as if the Baroque style announces the new eighteenth-century sensibility that Trens suggested, which is offended by, or at least made uncomfortable by, bodily manifestations of Mary's motherhood.

From a theological point of view, Mary's cloak is a way of visually representing Mary's protective maternal vocation. Indeed, in many images, this cloak covers her devotees from their enemies. Under her protective cloak, important people, social bodies (brotherhoods, friars), the multitude and souls in purgatory are often represented. This is also the most frequent representation of Mary as mater omnium or Mary as the mother of all believers. The cloak thus becomes an important element in Marian representation. Figure 12 reflects its growing importance, confirming increasing images-invocations of Mary as protector, as seen in the previous section.

However, this representation of Mary contains some novelty in terms of her relationship with her devotees, and therefore her motherhood. In these images, the ties between individuals disappear and they are all situated more or less on the same plane; in turn, the outer limit, i.e., the Virgin's cloak, is clearly marked and acts as a protective border that is outside of the group. In this visual metaphor, historical-genealogical relationships disappear in favor of a spatialized image of a group of devotees. In other words, this motherhood does not appeal to a common origin or to a founding past; it is a "new" kind of motherhood that is entirely the work of grace. She is mother Mary to all believers in the universal Church rather than to a community defined in terms of blood or a community of origin. 


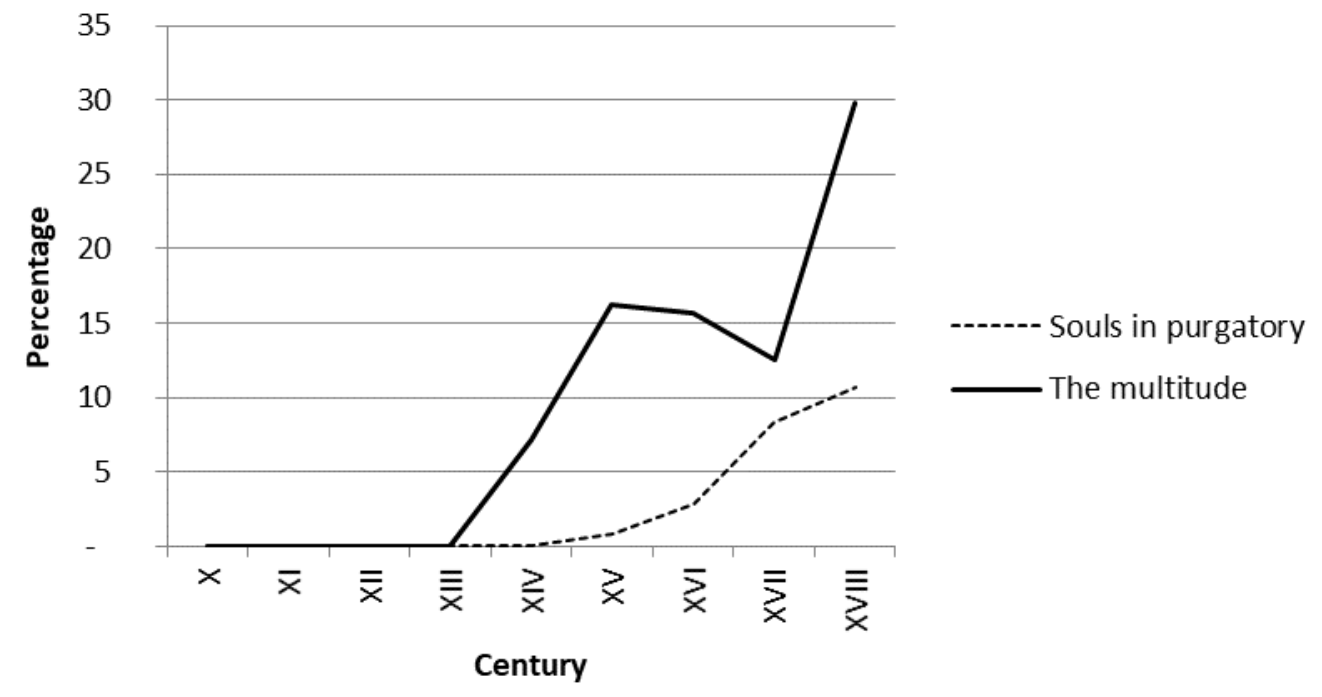

Figure 12. Mary protects the multitude under her cloak (Spain, tenth to eighteenth centuries). Source: Authors' elaboration based on Trens (1946).

This observation is relevant here because, for many authors, this same process, which was present at the political level, was the necessary condition for the emergence of the Modern State, and also impacted the aristocracy. ${ }^{15}$ Personal ties, which were typical of feudalism, started to lose importance in favor of a territorial vision of power. Anyone within the territory under the sovereignty of the State became part of the same political community. A border thus acquires new political significance in that, outside the group, it delimits the community.

This spatial vision of relationships contrasts with other representations of Mary present since the eleventh century (Trens 1946, p. 98) like the Tree of Jesse. This iconographic category is an attempt to represent the immaculate conception, but started to decline in importance until it was in the minority of representations in the sixteenth century and then disappeared shortly thereafter. Jesse is David's father and, therefore, originator of the lineage that contains the promise of the Messiah. In these representations, Mary appears as the perfect fruit that gives meaning to the whole tree because, through her, the promises made to Abraham are to be fulfilled. ${ }^{16}$

In these representations, the visual metaphor used is that of a tree whose roots sink into Jesse's body and from whom the entire trunk and its branches-his descendantscome. Mary, for her part, is at the top. A historical-genealogical vision dominates and personal ties between individuals stand out; multi-generational in nature, they explain the group's origin and development ordered from the base to the top (chronological), and leave the group's limits loosely defined. In this image, group cohesion comes from within and from direct personal ties. Undoubtedly, this is a very lineage-focused image of Mary's origin in tune with the representations that aristocracies and monarchical dynasties of old fostered.

With the passage of time, the Tree of Jesse tended toward simpler forms. One variant highlights the marriage of Joachim and Anne within the tree (who are one size larger than the rest of the figures and are centrally positioned). In others, Mary appears surrounded by her immediate family (Trens 1946, pp. 109-12). Perhaps the most interesting one is what Trens calls Triple Saint Anne (Trens 1946, pp. 119-20). Essentially, these images present Jesus on Mary's lap, who, in turn, is seated on Saint Anne's lap, her own mother. ${ }^{17}$

These representations-which peaked in the fifteenth century and quickly declined thereafter-are, in a certain sense, a very simplified Tree of Jesse. Yet, in another sense, they radically change what the image intends to express. In representations of the Tree of Jesse, the idea prevails that Mary, as a descendant of Jesse, is destined to fulfill the promises 
made to Abraham with her motherhood. Mary thus appears as a member of the chosen people through whom the promised Messiah, her son, will arrive.

However, images with a Triple Saint Anne emphasize something slightly different. There, the main message is Mary's immaculate conception. If Mary was conceived without original sin, how was her immaculate conception possible from sinful parents? This goes straight to the problem of original sin, which is transmitted to all mortals generation after generation. If Saint Anne had original sin, how did she not transmit it to her daughter? One possible answer, the one that Triple Saint Anne seems to suggest, is that Saint Anne was herself immaculately conceived. But this answer immediately seems inadequate since it does not account for the sanctity of Mary's grandmother and so on. The theological argument ultimately given is that Mary's immaculate conception was a privilege granted in anticipation of Jesus Christ's merits; that is, it was an exception. Thus, it reinforces the power of grace beyond and above natural bonds, as well as the strength and novelty of the incarnation and the idea that Mary is the "new" Eve who will give rise to a new humanity incarnated in the Church.

If Mary is a novelty, a condition she shares with her son, who is not justified by inherited privileges and subject to the limitations of original sin, the problem is solved and it is no longer necessary to justify her motherhood based on lineage. Likewise, there is no longer any limitation on expressing Mary's power as mater omnium. She is the new Eve, destined to unite the human race through the Church and with her universal motherhood that is beyond space and time. She helps to explain the Church's power to encompass all humanity, without losing her sense of family. Although from the beginning of Catholic Tradition, Mary has been seen as the mother of God, of men, and of the Church, the development of Marian art sheds light on how large groups have publicly and historically expressed their condition as children of Mary through images and invocations. As quantified in Figure 12, Trens' study suggests that, from the eleventh century onward, the development of Marian art shows how assorted groups began to invoke Mary. First came the religious orders, especially Franciscans and Dominicans, then the confreres, who placed their brotherhood under the invocation of the Virgin, then sinners and, finally, the souls of purgatory. The spatial expression of Mary's maternal relationships with her children reinforces the idea of a new humanity capable of breaking with the miseries and limitations set upon us by original sin. Mary thus expresses the newfound freedom enjoyed by the children of God, who are free from the bonds of sin that all bloodlines pass down.

\section{Conclusions: The Subtle Obscuring of Mary's Maternal Side}

We have seen how devotion to Mar-although always present in Christianity- became part of mass culture starting in the eleventh century in tandem with religious orders' work. At that time, Christian culture was making an enormous effort to unite reason and faith, which gave rise to new dilemmas.

Undoubtedly, Mary's most exalted gifts are her human-divine motherhood, her virginity, and her immaculate conception and, in a certain sense, they are all inseparable. In Mary, consanguinity and grace are united in perfect harmony. But, in another sense, it can be said that, of all her gifts, the greatest is by far her maternity.

Christian culture presents Mary's femininity by highlighting her human and divine maternity. Mary is presented as the model woman who perfects femininity. Therein, consanguinity and grace, the human and the divine, earth and sky naturally unite. Mary's motherhood further explains Jesus' human and divine condition, which are essential for the incarnation and redemption to take place. Without the incarnation-and without Mary's maternal response, redemption would not have been possible. We have seen how, in representing Mary's motherhood, both bodily and spiritual, human, and divine, it becomes the seat of the most sublime divine realities. Everything in the represented relationship contributes to a divine exaltation of the human condition.

In Marian representations over the centuries, Mary's closeness to her son stands out, whether in her welcoming lap or in her victorious arms, the whole scene exalts the joy of 
her divine and human motherhood, making her a model worth looking up to. Furthermore, her closeness and naturalness as a mother make her an imitable model. Mary's mother-son relationship is the source of her most public or visible identity; it is the fundamental task that justifies her life. In giving birth to Christ, a human being, she gives birth to the hope that all humanity will be reunited as a family again. Thus, the redemption comes to and makes its home in the human realm through Mary's motherhood, her closeness, and her absolute willingness. For this reason, Mary founds the Church around herself; she is the Church in so far as the Body of Christ, and she makes the Church a family. Mary's body, seat of the Church's body, appears as the effective and powerful sign of the unconditional gift-of-self that she manifests as part of her most profound identity. The human realm, transformed by grace, opens up to the divine without limits, thus reaching unanticipated perfection.

However, starting with modernity, little by little a shy modesty began to envelop Mary's humanity to the point that representations of her as pregnant or breastfeeding declined. In the Modern Age, the diffusion of the French cloak, which expresses Mary's universal maternal protective power for all believers, ends up completely hiding her maternal body. Thus, while Mary was universalized, representations of her motherhood were spiritualized with the fullness of grace.

In iconographic representation, Mary went from sitting in a welcoming and majestic posture (mercifully supporting her son's redemptive work), where mother and son look expectantly at the devotee, to being represented standing, glorious, and with a triumphant posture, while her motherhood began to be represented less and less, and appears more problematic when depicted. It is seen as affective and "too" human to understand and accept her son's work of redemption on the cross. In the end, representations of Mary immaculate came to dominate; there, she is young and in the fullness of her beauty, charm, and grace. She stands in glory alone, single, without her son, and without the relationships that establish her identity. In these representations, her femininity no longer appears explicitly maternal. This evolution corresponds to a certain crisis that originated in the sixteenth century related to invocations that present Mary as a joyful mother in favor of invocations that present her as a powerful intercessor. This crisis is strongest in large cities immersed in economic expansion driven by the commercial revolution. ${ }^{18}$

The crisis of Mary as a model of joyful motherhood is linked to an increasingly spiritualized representation thereof, more glorious, but less welcoming; more powerful, but less merciful, more sorrowful, but less joyful. This does not correspond to a doctrinal evolution, but rather to an emotional climate, what we could qualify as a certain cultural unconscious. The body language in the images studied suggests a certain crisis in the value of motherhood itself as a source of essential feminine identity and, when linked to grace, in the redemptive power of man and the world. This is not a consciously formulated and rationalized crisis, but rather what we could qualify as a certain decline of the divine found in the human realm, which can be glimpsed in a plethora of small details.

Author Contributions: Conceptualization, A.M.-A. and G.S.; methodology, A.M.-A.; software, A.M.A.; validation, A.M.-A.; formal analysis, A.M.-A. and G.S. investigation, A.M.-A.; resources, A.M.-A.; data curation, A.M.-A.; writing-original draft preparation, A.M.-A. and G.S.; writing-review and editing, G.S.; visualization, A.M.-A. and G.S.; supervision, A.M.-A.; Project Administration, G.S.; Funding Acquisition, G.S. All authors have read and agreed to the published version of the manuscript.

Funding: This research was funded by Universidad Panamericana, grant number: UP-CI-2021-MEX07-FCEE.

Institutional Review Board Statement: Not applicable.

Informed Consent Statement: Not applicable. 
Data Availability Statement: The data presented in this study are available and can be requested from the corresponding author.

Conflicts of Interest: The authors declare that they have no conflict of interest.

\section{Appendix A}

(1) Examples of Mary sitting (majestic) and standing (glorious).

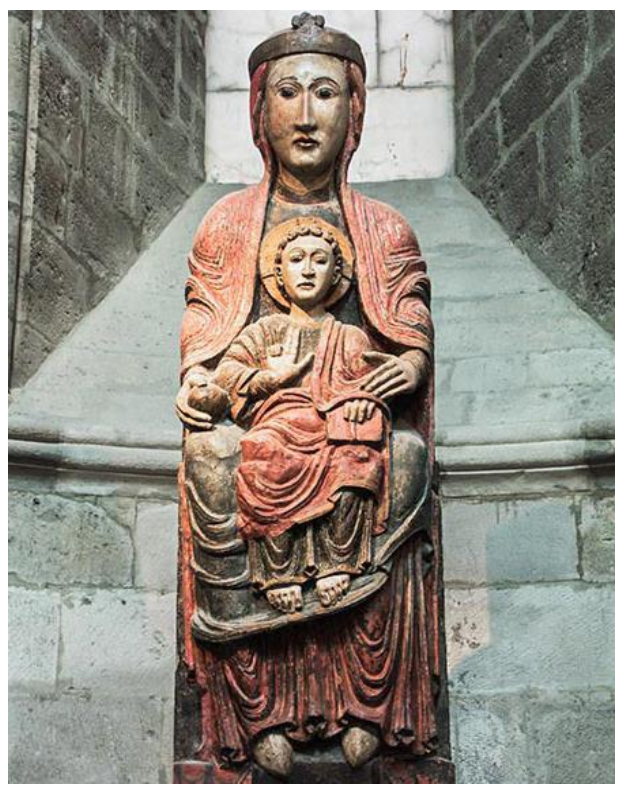

(a)

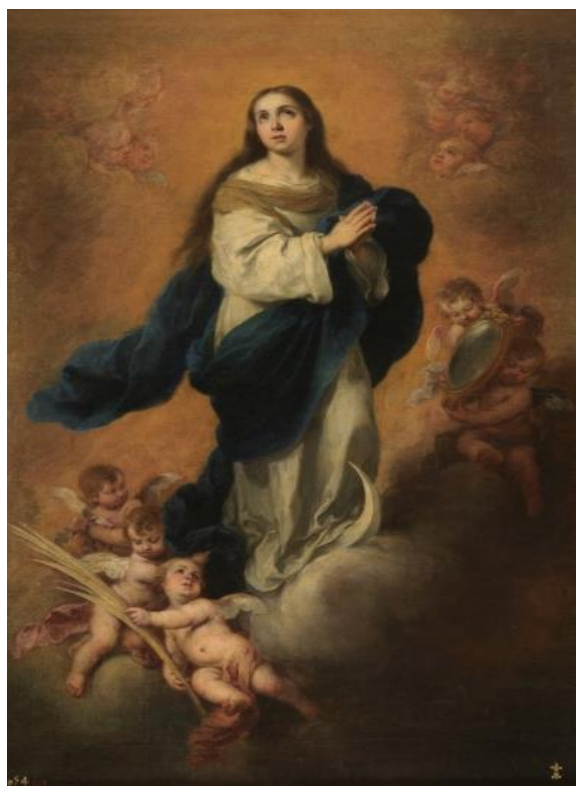

(b)

Figure A1. (a). María entronizada, Thirteenth century, Catedral de Tudela (Navarra, Spain) (left); (b) Bartolomé Esteban Murillo, “La Inmaculada Concepción,” 1665-1675, Museo Del Prado (Madrid, Spain) (right).

(2) Mary and Child's gazes and intimacy.

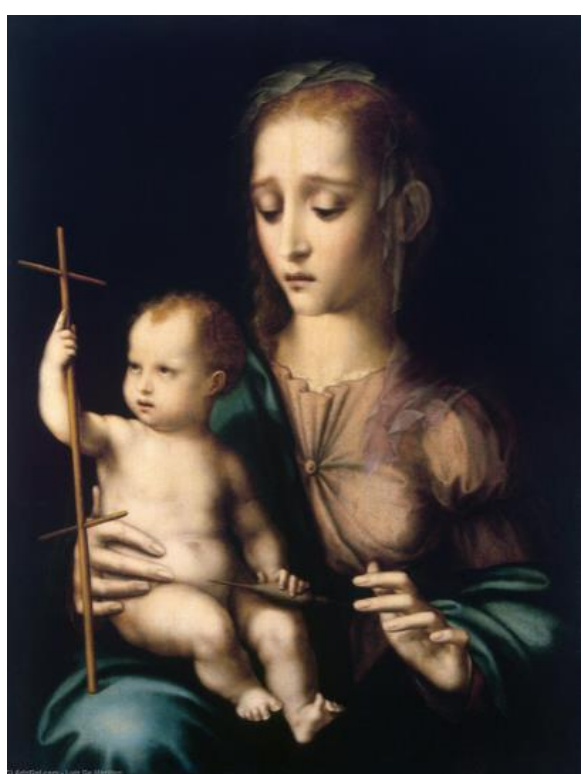

(a)

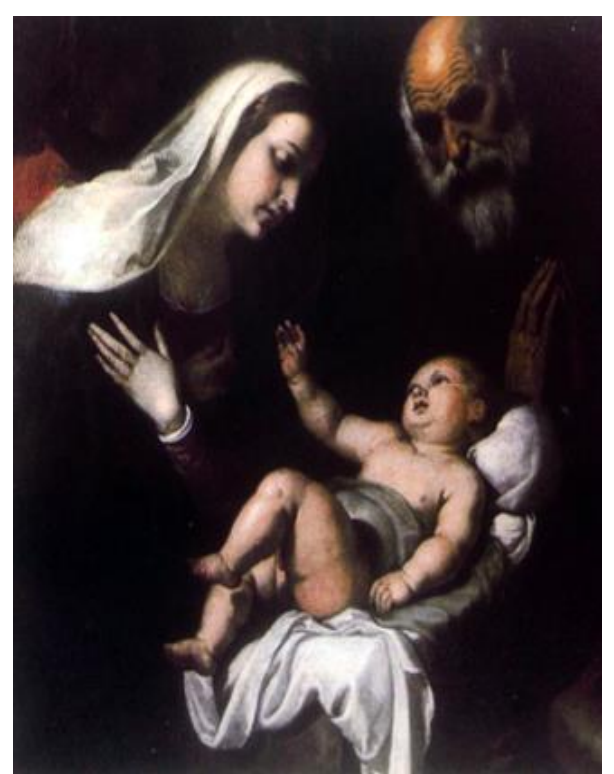

(b)

Figure A2. (a). Luis de Morales, “Virgen con el niño," 1570, The Hermitage (St. Petersburg, Russia). (left); (b). Francisco Ribalta, “Nacimiento," 1565-1628, Colegio del Corpus Christi (Valencia, Spain). (right). 


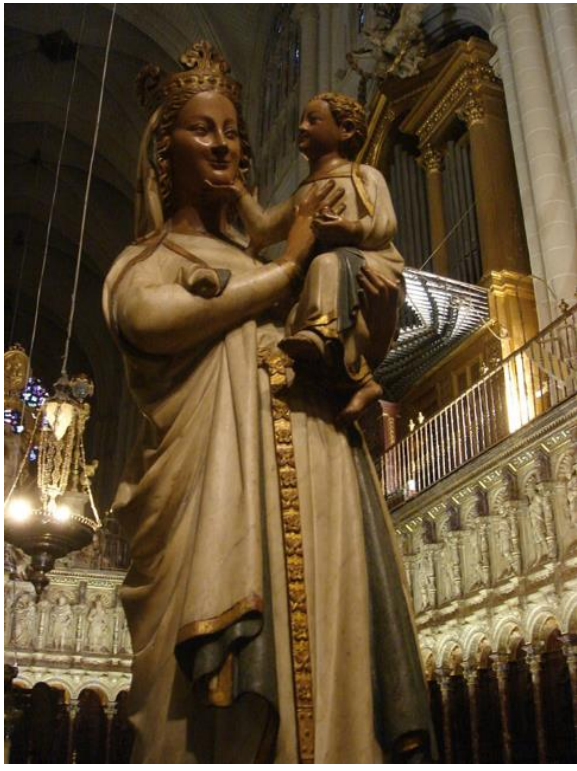

(a)

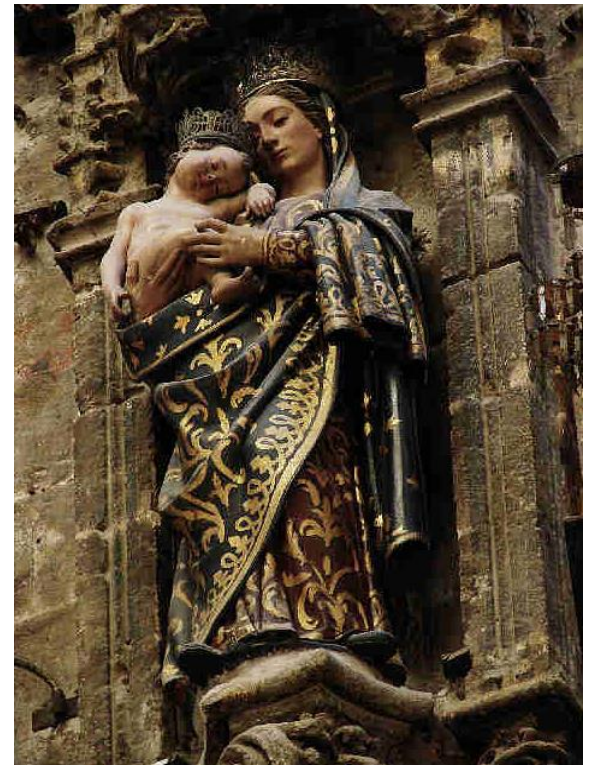

(b)

Figure A3. (a). Virgen blanca, second half of the Fifteenth fifteenth century, Toledo Cathedral (Toledo, Spain). (left); (b). Virgen del Reposo de Norabuena, 1556, Seville Cathedral (Seville, Spain). (right).

(3) Signs of Mary's maternity.

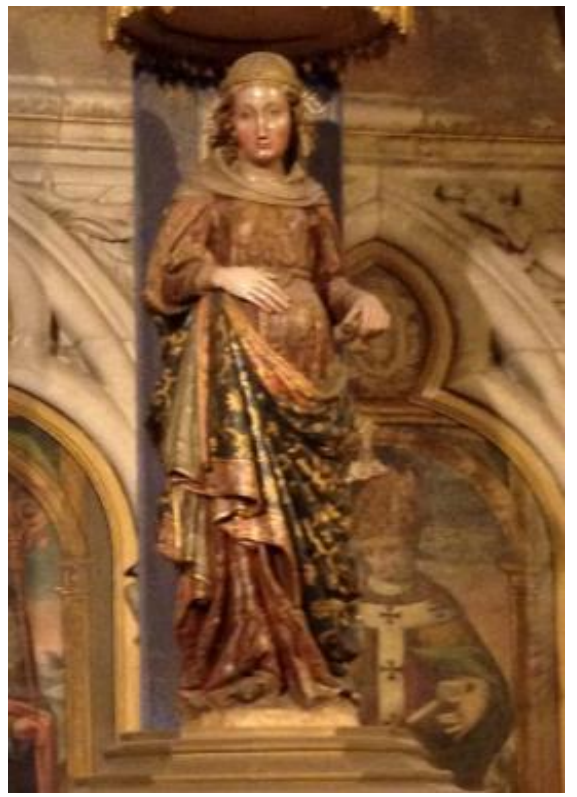

(a)

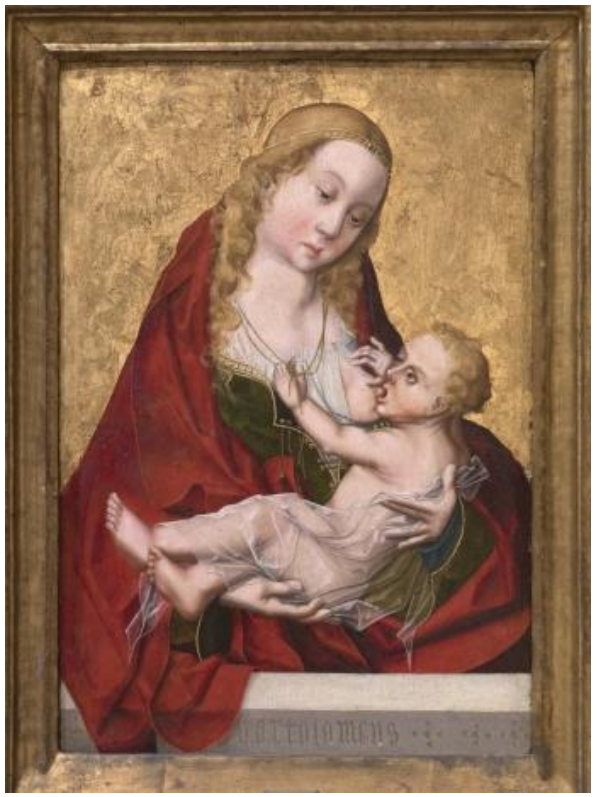

(b)

Figure A4. (a). Our Lady of Hope, late thirteenth century, Leon Cathedral (Leon, Spain). (left); (b). Maestro Bartolomé, “Virgen de la leche," 1490, Museo Del Prado (Madrid, Spain). (right).

\section{Notes}

1 Regarding the images referred to in the text and considering the large number (around 400) of paintings, photos, and sculptures here examined, we have decided not to include all of them. In order not to distract the reader, and aiming to offer some examples, in the Appendix A we provide a small sample of images that contain the most salient topics addressed in this article.

2 Of course, we do not mean that maternal giving is reduced to pregnancy and lactation, or to exclusively physical terms. Dozens of small daily sacrificial tasks accompany motherhood throughout childrearing. We only intend to highlight here that, during pregnancy and lactation, the mother-child relationship is established in such a way that the body begins to express the unique role that one has for the other, especially for the child. No one can replace the mother during pregnancy and one can only do 
so with great difficulty during lactation. Indeed, historical demographics have amply demonstrated that, in the past, a child's chances of survival without breastfeeding were very small (70-90\% mortality rate in the first year of life). See: Tilly et al. (1979). Furthermore, a child fed by a wet nurse was less likely to survive than a child who was breastfed by her mother (See Bardet 1983).

3 All quotes from Trens were translated from Spanish to English by the authors.

4 The Apocalyptic Virgin refers to the attempt to represent the Virgin as described in a passage from St. John's Book of Revelation (Chapter 12): "Now a great sign appeared in heaven: a woman, robed with the sun, standing on the moon, and on her head a crown of twelve stars. She was pregnant, and in labor, crying aloud in the pangs of childbirth. Then a second sign appeared in the sky: there was a huge red dragon with seven heads and ten horns, and each of the seven heads crowned with a coronet. Its tail swept a third of the stars from the sky and hurled them to the ground, and the dragon stopped in front of the woman as she was at the point of giving birth, so that it could eat the child as soon as it was born. The woman was delivered of a boy, the son who was to rule all the nations with an iron scepter." In both the Orthodox and Catholic iconographic traditions, that woman is Mary and the child is Jesus.

5 Mary appears with the Christ Child on her lap or in her arms, which clearly and visually highlights her maternity.

6 The other postures are far and away in the minority, including kneeling, 4\% and a bust, 5\%. The scarce representation of Mary kneeling is of note (when she is kneeling, it is usually before her son or God the father). The overwhelming prevalence of the sitting and standing positions speaks indirectly to an almost unanimous feature of the Christian tradition, namely the enormous dignity of Mary in the eyes of God.

$7 \quad$ Mary's authority and liturgical leadership is clear when she is represented standing and holding a chalice, flanked by the apostles, as, for instance, is the case of the images on main apses of St. Clement of Tahull (Catalonia, Spain) and Santa Maria de Ginestarre (Lleida, Spain). According to Lidov (2017), starting in the eleventh century, the image of a crowned female figure holding out the Eucharistic chalice (Ecclesia) became common in Byzantine iconography and represents the Virgin Mary's priesthood, as well as parallels the Virgin with the Church.

8 Children represented in the High Middle Ages are not very child-like; they usually look like adults. See Ariès (1987).

9 Outward-looking gaze, $25 \%$; and converging gaze, $15 \%$.

10 The sum of types a and e in Figure 8.

11 The sum of types $\mathrm{d}$ and $\mathrm{g}$ in Figure 8.

12 The sum of types $\mathrm{b}$ and $\mathrm{c}$ and $\mathrm{d}$ in Figure 8.

13 "As a general rule, the Virgin Mary carries the Christ Child on her left arm in accordance with maternal instinct, which can be seen in daily family life. The right hand is thus ready to caress the child or to be used for diverse tasks and postures. This is observed almost constantly in statues of Our Lady. Mary rarely carried the child on her right arm. Paintings are not as consistent, especially when it comes to seated representations of Mary" (Trens 1946, p. 610).His interpretation of the phenomenon-leaving the mother's right hand free-is not usually accepted in the literature since in many cases, left-handed mothers also mostly hold their child on the left.On the other hand, the expression "maternal instinct" does not seem very accurate since it does not capture the body's role as gift-of-self in the mother-child relationship. It does pick up on the idea of the inner strength that drives mothers, but this inner force is guided by intelligence and the will; it mobilizes rather than nullifies them.

14 At this time, the doctrine of "pure nature" began to develop in theology. It gave rise to new dilemmas for reconciling the natural and the supernatural. See De Lubac (1970).

15 In proofs of nobility throughout the sixteenth and seventeenth centuries, lineage tended to lose importance compared to evidence of coming from "known land." In this sense, the title of a text that tries to synthesize the main changes in Navarrese nobility from the fifteenth to the seventeenth centuries is relevant. See Moreno-Almárcegui and García-Bourrellier (2003).

16 We owe this idea to Eloy Tejero. See especially his text "María, Arca de la Alianza" (Tejero 2013).

17 The phenomenon is very general since, in Latin, these representations are called Mettertia, in Italian Metterza, and in German Selbstdrit. All allude to the idea of triplets, that is, the idea of one that goes with two others.

18 According to De Vries (1987), during the Modern Age, two types of large metropolises emerged, constituting the principal transformations to the European urban network, including commercial ports and capitals of new modern States. Both were related to the organization of large regional and international markets, in both economic and political matters. In other words, this transformation explains the era of commercial capitalism and its development was key to the later emergence of the Industrial Revolution.We have also analyzed the construction of Marian sanctuaries to study the evolution of devotion to Mary in Mediterranean countries during the fifth to tenth centuries. Although it supports the thesis presented here, said study exceeds the limits of this article and will be the subject of a separate publication.

\section{References}

Ariès, Philippe. 1987. El Niño y la Vida Familiar en el Antiguo Régimen. Madrid: Taurus.

Bardet, Jean-Pierre. 1983. Rouen aux XVIIe et XVIIIe Siècles: Les Mutations d'un Espace Social, 2nd ed. Paris: Collection Regards sur l'histoire.

De Lubac, Henri. 1970. El misterio de lo Sobrenatural. Barcelona: Estela. 
Caillé, Alain. 2000. Anthropologie du Don. Le Tiers Paradigme. Paris: Desclée de Brouwer.

Christian, William. 1976. De los santos a María. In Temas de Antropología Española. Barcelona: Akal.

De Vries, Jan. 1987. La Urbanización de Europa 1500-1800. Barcelona: Crítica.

Donnot, Julien, and Jacques Vauclair. 2005. Biais de latéralité dans la façon de porter un très jeune enfant: Une revue de la question. Side preferences in infant holding: A review. Neuropsychiatrie de l'Enfance et de l'Adolescence 53: 413-25. [CrossRef]

Godbout, Jacques, and Alain Caillé. 2010. L'espirit du Don. Paris: La Dècouverte \& Syros.

Grüsser, Otto-Joachim. 1983. Mother-Child Holding Paterns in western Art: A Developmental Study. Ethology and Sociobiology 4: 89-94. [CrossRef]

Haya, Fernando. 1997. El ser Personal. De Tomás de Aquino a la Metafísica del Don. Pamplona: EUNSA.

Lidov, Alexei. 2017. The Priesthood of the Virgin Mary as an Image-Paradigm of Christian Visual Culture. IKON 10: 9-26. [CrossRef]

Moreno-Almárcegui, Antonio. 2016. La devoción a san José ¿un nuevo modelo de virilidad?: El caso de España. Siglos XV al XVIII. Cauriensia, Revista Anual de Ciencias Eclesiásticas 9: 245-86.

Moreno-Almárcegui, Antonio, and Rocío García-Bourrellier. 2003. De los linajes a los solares. Los cambios en el papel de las mujeres de las élites navarras. Siglos XV-XVII. In Familia y Cambio Social en Navarra y País Vasco. Edited by C. Fernández and A. Moreno. Pamplona: Instituto de Ciencias para la Familia, Navegraf.

Moreno-Almárcegui, Antonio, and Germán Scalzo. 2019. Entre don y Contrato: Una Historia de la Comprensión del Matrimonio. Pamplona: EUNSA.

Polo, Leonardo. 2015. Lo radical y la libertad. In Cuadernos de Anuario Filosófico. Pamplona: Servicio de Publicaciones UNAV.

Ratzinger, Joseph. 2001. El Espíritu de la Liturgia: Una Introducción. Madrid: Ed. Cristiandad.

Sabbé, Et. 1951. Le culte Marial et la Genèse de la Sculture Medievale. Revue Belge d'Archeologie et d'Histoire de l'Art 2: 101-25.

Scalzo, Germán, Antonio Moreno Almárcegui, and Maria de los Ángeles Padilla. 2018. Rebuilding the Temple of Graces: Gift-giving as the Foundation of Care. OEconomia. History, Methodology, Philosophy 8: 139-55. [CrossRef]

Tejero, Eloy. 2013. María, Arca de la Alianza. ScrdeM. pp. 23-36. Available online: https://www.torreciudad.org/wp-content/ uploads/2018/10/scripta_2013_tejero.pdf (accessed on 30 October 2021).

Tilly, Louise A., Rachel G. Fuchs, David I. Kertzer, and David L. Ransel. 1979. Child Abandonment in European History: A Symposium. Journal of Family History 17: 1-23. [CrossRef]

Trens, Manuel. 1946. María. Iconografía de la Virgen en el Arte Español. Madrid: Plus-ultra. 